\title{
The effect of legume protease inhibitors on native milk and bacterial proteases
}

\author{
Richards Melanie, De Kock Henrietta Letitia, Duodu Kwaku G, Buys, Elna Maria.* \\ Department of Food Science, University of Pretoria, Pretoria, 0001, South Africa \\ melanie.richards@up.ac.za, riette.dekock@up.ac.za, elna.buys@up.ac.za
}

*Corresponding author: Tel: +27 12 4203209; E-mail address: elna.buys@up.ac.za

\begin{abstract}
Protease inhibitors from legume seed extracts (soybean, cowpea and marama beans) and purified soybean protease inhibitor were evaluated with regards to their abilities to inhibit proteases produced by important milk contaminating bacteria, i.e. Bacillus spp. and Pseudomonas spp., and native milk protease, plasmin. Although heattreatment is the most common mean of inactivating enzymes, some heat-stable enzymes can survive the ultra-high temperature (UHT) processing of milk and cause sensory and consistency defects during storage at room temperature. The legume protease inhibitors reduced the activity of plasmin and proteases produced by Bacillus spp. by up to $94 \%$ and $97 \%$, respectively, while it showed low inhibitory activity towards $P$. fluorescens proteases $(19 \%)$ in a buffer system. The protease inhibitors reduced the activity of plasmin (41\%) and Bacillus proteases $(50 \%)$ in UHT milk, however to a lesser extent as compared to inhibition in the buffer system; while it had little or no effect on proteases from Pseudomonas spp. Legume protease inhibitors show great potential in preventing or reducing proteolytic activity of Bacillus proteases and plasmin and may be exploited in various applications where these proteases cause sensory or consistency defects in the product.
\end{abstract}

Keywords: UHT milk, legume protease inhibitors, bacterial proteases, plasmin

\section{Introduction}

Proteolysis of UHT milk during storage at ambient temperature limits both the shelf life and market potential of the milk (Datta \& Deeth, 2001) and has been attributed to extracellular heat-stable proteases produced by psychrotrophic bacterial contaminants 
of raw milk and natural milk alkaline serine protease, plasmin (Visser, 1981; Grufferty \& Fox, 1988; Datta \& Deeth, 2003). Protease activity in UHT milk is associated with changes in the flavor and viscosity of the milk, with the eventual formation of a gel (McMahon, 1995; Chen, Daniel, \& Coolbear, 2003; Datta \& Deeth, 2003). Off-flavors, such as bitterness, in UHT milk are associated with the release of tyrosine in the milk (Gebre-Egziabher, Humbert, \& Blankenagel, 1980; Datta \& Deeth, 2003), while viscosity changes are associated with the hydrolysis of caseins (Chen et al., 2003; Datta \& Deeth, 2003). During the course of the latter, the enzymes release the $\beta$-lactoglobulin- $\kappa$-casein complex ( $\beta \kappa$-complex), formed during heat treatment, from the casein micelle. Subsequent aggregation of the released $\beta \kappa-$ complexes forms a three-dimensional cross-linked protein network, which causes gelation of the milk (McMahon, 1995).

Bacterial contaminants are mainly introduced into milk within the interior of the udder, the cow's teats and milking and storage equipment (Law \& Mabbitt, 1983). Contaminating milk bacteria often isolated from refrigerated milk and associated with proteolysis in milk are mainly species from Pseudomonas, particularly P. fluorescens (Fairbairn \& Law, 1986; Kohlmann, Nielsen, \& Ladisch, 1991; Matselis \& Roussis, 1998). In addition, Bacillus species are abundant in the environment and can contaminate milk during production, handling and processing (Phillips \& Griffiths, 1990; Matta \& Punj, 1999). Although the contaminating milk bacteria are mainly psychrotrophs that are eliminated by the UHT process, many of their enzymes survive and remain active in the derived dairy products where they can cause problems during storage (Sørhaug \& Stepaniak, 1997; Chen et al., 2003). The plasmin system is complex and not only comprise plasmin, but also plasminogen (plasmin precursor), plasminogen activators, plasmin inhibitors and inhibitors of plasminogen activators (Upadhyay, McSweeney, Magboul, \& Fox, 2004). Plasminogen is more heat stable than its active form and can be activated by cleavage of a single peptide bond by even more heat stable activators (Lu \& Nielsen, 1993; Aroonkamonsri, Aroonkamonsri, \& Kakuda, 1996).

Various studies show the potential of protease inhibitors in preventing or reducing adverse effects of proteases in food products. Examples of this include the use of $\alpha-$ 2-macroglobulin to inhibit protease activity in various fish species that previously 
prevented the use of these species in processed fish products (Lorier \& Aitken, 1990), and the use of protease inhibitors to improve the gel properties of frozen squid muscle (Peréz-Mateos, Montero \& Gómez-Guillén, 2002). Legume seeds contain protease inhibitors with the ability to inactivate proteases by various mechanisms. The objective of this study was to examine the effect of protease inhibitors from legume seeds, i.e. soybeans (Glycine max (L.) Merr), marama beans (Tylosema esculentum (Burch) A. Schreib) and cowpeas (Vigna unguiculata (L.) Walp), on the proteolytic activity of native milk protease plasmin and proteases from bacterial contaminants previously isolated from milk, all known to cause adverse effects during the storage of UHT milk.

\section{Materials and methods}

\subsection{Materials and chemicals}

Savinase and Alcalase were supplied by Novozymes, Johannesburg, South Africa. Plasmin, bovine trypsin, azocasein, bovine serum albumin (BSA), purified soybean trypsin inhibitor and Tyr-Leu were obtained from Sigma-Aldrich, Kempton Park, South Africa. The rest of the chemicals and standards were of analytical grades and obtained from Sigma-Aldrich or Merck (Johannesburg, South Africa) unless otherwise stated.

\subsection{Protease inhibitor extraction}

\subsubsection{Preparation of flours}

Seeds from marama bean were dehulled using a cracker (WMC Sheet Metal Works, Tzaneen, South Africa) and soybeans were dehulled using a Tangential Abrasive Dehulling Device (TADD). After the dehulled seeds were milled in a food blender, the flour was defatted twice with n-hexane $(1: 5 \mathrm{~m} / \mathrm{v})$ for an hour each time, air-dried and milled again. This process was repeated and defatted flour was placed in a fume hood overnight to remove the remaining hexane. The defatted flour was milled again to pass through a $1000 \mu \mathrm{m}$ mesh. Due to the low fat content of cowpeas, it was 
milled to pass through a $1000 \mu \mathrm{m}$ mesh and used for protein extraction without any defatting.

\subsubsection{Protein extraction}

The protein was extracted following the protocol of Maggo, Malhotra, Dhawan, and Singh (1999), with a few modifications. Flours were extracted with 0.1 mol. $\mathrm{L}^{-1}$ phosphate buffer, $\mathrm{pH} 7.5$, at a ratio (flour:buffer) of $1: 20(\mathrm{~m} / \mathrm{v})$ for $4 \mathrm{~h}$ at room temperature in a shaking water bath. The suspension obtained was centrifuged at 10 $000 \times g$ for $30 \mathrm{~min}$ and the supernatant was collected and used for determining the protein and total phenolic contents and the trypsin inhibitor activity.

\subsection{Characterization of protein extract}

\subsubsection{SDS-PAGE}

The method described by Taylor, Bean, Ioerger, and Taylor (2007) was used for SDS-polyacrylamide gel electrophoresis (SDS-PAGE). Aliquots of protein extracts (15 $\mu \mathrm{L}$ ) containing $15 \mu \mathrm{g}$ protein was loaded onto 4-12\% polyacrylamide gradient gels. Gels were stained with Coomassie Brilliant Blue R-250.

\subsubsection{Native-PAGE}

Native-PAGE was performed using the NativePAGETM Novex ${ }^{\circledR}$ Bis-Tris Gel system (Invitrogen $^{\mathrm{TM}}$, Johannesburg, South Africa). The Native-PAGE gels were stained for trypsin inhibitor activity as described by Ee, Zhao, Rehman, and Agboola (2008).

\subsubsection{Quantification of protein concentration in crude protein extracts}

The method of Bradford (1976), with the following modifications, was used to determine the protein concentration of the crude protein extracts. Aliquots of these extracts $(20 \mu \mathrm{L})$ were pipetted into the wells of a 96-well polystyrene microtiter plate, followed by addition of $40 \mu \mathrm{L}$ of Bradford's Reagent. The final volume in the 
wells was made up to $200 \mu \mathrm{L}$ with the addition of $\mathrm{dH}_{2} \mathrm{O}$ and the absorbance was measured at $595 \mathrm{~nm}$ against a reagent blank. A BSA standard curve was prepared and the protein concentration in the crude protein extracts was determined using the standard curve. Results were expressed as mg protein per $\mathrm{mL}$ crude extract.

\subsubsection{Quantification of total phenolic content in crude protein extracts}

The total phenolic content in the crude protein extracts was determined using the Folin-Ciocalteu procedure described by Hagerman, Harvey-Mueller, and Makkar (2000). A catechin standard curve was prepared and used to determine the total phenolic content in the protein extracts. Results were expressed as catechin equivalents (CE, mg catechin equivalents /100 mg sample) on dry basis. The dilution factor of flour to buffer $(1 \mathrm{~g}$ : $20 \mathrm{~mL})$ were taken in account in calculating the dry basis of the protein extracts.

\subsubsection{Quantification of trypsin inhibitor activity in crude protein extracts}

Equal volumes of protein extracts $(60 \mu \mathrm{L})$ and trypsin $(375$ protease units $(\mathrm{PU}) / \mathrm{mL})$ were mixed and incubated for $1 \mathrm{~h}$ at $25{ }^{\circ} \mathrm{C}$. The activity of trypsin inhibitor was assayed by determining the residual trypsin activity following the method of Secades, and Guijarro (1999) using azocasein as substrate and bovine trypsin as standard enzyme. A soybean trypsin inhibitor standard curve was prepared and used to determine the trypsin inhibitor activity (TIA) in the protein extracts. Results were expressed as trypsin inhibitor units (TIU) per $\mathrm{mL}$ by determining the trypsin units inhibited per $\mathrm{ml}$ extract relative to that of controls that contained only enzyme and no crude extract.

\subsection{Inhibition of bacterial protease and plasmin activity in buffer}

\subsubsection{Bacterial protease inhibition assay}

Alcalase and Savinase are alkaline proteases (E.C. 3.4.21.62) produced by Bacillus licheniformis and B. lentus, respectively. P. fluorescens (ATCC 13525) (Quantum Biotechnologies, Randburg, South Africa) was cultured in tryptone soy broth (TSB) 
for 3 days at $25{ }^{\circ} \mathrm{C}$. Bacterial cells were removed by centrifugation at $24000 \times g$ for $10 \mathrm{~min}$ at $5{ }^{\circ} \mathrm{C}$. The resulting supernatants were stored at $-20{ }^{\circ} \mathrm{C}$ until used as crude protease source.

One volume $(60 \mu \mathrm{L})$ of either Savinase, Alcalase or P. fluorescens crude protease (at activities of $375 \mathrm{PU} / \mathrm{mL}$ as determined by the azocasein assay (Section 2.3.5) was mixed with one volume of crude extract from either soybeans or marama beans or cowpeas or purified soybean trypsin inhibitor at concentrations of 200, 287.5 and 375 $\mathrm{TIU} / \mathrm{mL}$. Inhibition of the bacterial proteases by the protease inhibitors from the various legume seeds was evaluated using the same method described in Section 2.3.5 except that bovine trypsin was replaced by the bacterial proteases. One unit of enzyme activity was defined as the amount that yielded an increase of 0.01 in the absorbance at $420 \mathrm{~nm}$ in $30 \mathrm{~min}$ at $30{ }^{\circ} \mathrm{C}$. The protease inhibitor activity (PIA) was defined as the percentage of protease units inhibited (PUI) relative to that of controls that contained only the enzyme and no crude extract. Blanks were prepared by adding $10 \%$ trichloroacetic acid (TCA) before the addition of the substrate.

\subsubsection{Plasmin inhibition assay}

Plasmin (E.C. 3.4.21.7) and protease inhibitor mixtures were prepared as described in Section 2.4.1 for the bacterial proteases. After incubation for an hour, the remaining plasmin activity was assayed using a colorimetric method described by Baldi et al. (1996), using Val-Leu-Lys-p-nitroanilide as substrate.

\subsection{Inhibition of bacterial protease and plasmin activity in low fat UHT milk}

To determine the inhibitory effect of the crude extracts on proteases in milk, plasmin or bacterial proteases (Alcalase, Savinase or P. fluorescens protease) and protease inhibitors (crude protein extracts from legumes and purified soybean trypsin inhibitor) were added to low fat UHT milk at final concentrations of $375 \mathrm{PU} / \mathrm{mL}$ and 375 $\mathrm{TIU} / \mathrm{mL}$, respectively. The samples were mixed and incubated at $25{ }^{\circ} \mathrm{C}$ for $1 \mathrm{~h}$. 


\subsubsection{Quantification of bacterial protease inhibition}

The 4\% TCA filtrates were prepared and analysed for peptides using reversed phase high performance liquid chromatography (RP-HPLC) as described by Le, Datta, and Deeth (2006). The peptides were quantified by measuring the peak areas using valleyto-valley integration and expressed as mmol Tyr-Leu equivalents by reference to a standard curve prepared with various concentrations of Tyr-Leu. The protease inhibitor activity (PIA) was defined as the percentage of protease units inhibited (PUI) relative to that of controls that contained only the enzyme and no crude extract.

\subsubsection{Quantification of plasmin inhibition}

After incubation at $25{ }^{\circ} \mathrm{C}$ for $1 \mathrm{~h}$, the samples were prepared according to the method described by Richardson and Pearce (1981) with a few modifications to determine the residual plasmin activity. Sodium citrate solution $\left(0.4 \mathrm{~mol} . \mathrm{L}^{-1}\right)$ was added to milk samples $(1 \mathrm{~mL})$ in a 1:3 ratio (citrate: milk) and the mixture was centrifuged at $27000 \times g$ for $15 \mathrm{~min}$. The supernatant was collected and centrifuged twice at $15000 \times g$ for $15 \mathrm{~min}$. Residual plasmin activity was determined using the collected supernatant by the method described in Section 2.4.2

\subsection{Statistical analysis}

All experiments were performed in triplicate and data obtained was analysed by oneway analysis of variance (ANOVA). Protease inhibition data was analysed using factorial ANOVA. Mean differences were evaluated at the $95 \%$ significance level $(p$ $\leq 0.05$ ) using the Least Significant Different test. The analyses were performed using Statistica Version 10.0 (Statsoft, Tulsa, USA).

\section{Results and discussion}

\subsection{Characterization of the protein extracts from legume seeds}

The band patterns obtained on the SDS-PAGE gel compare well with work from other researchers (Fig. 1), indicating that these extracts were representative of the 


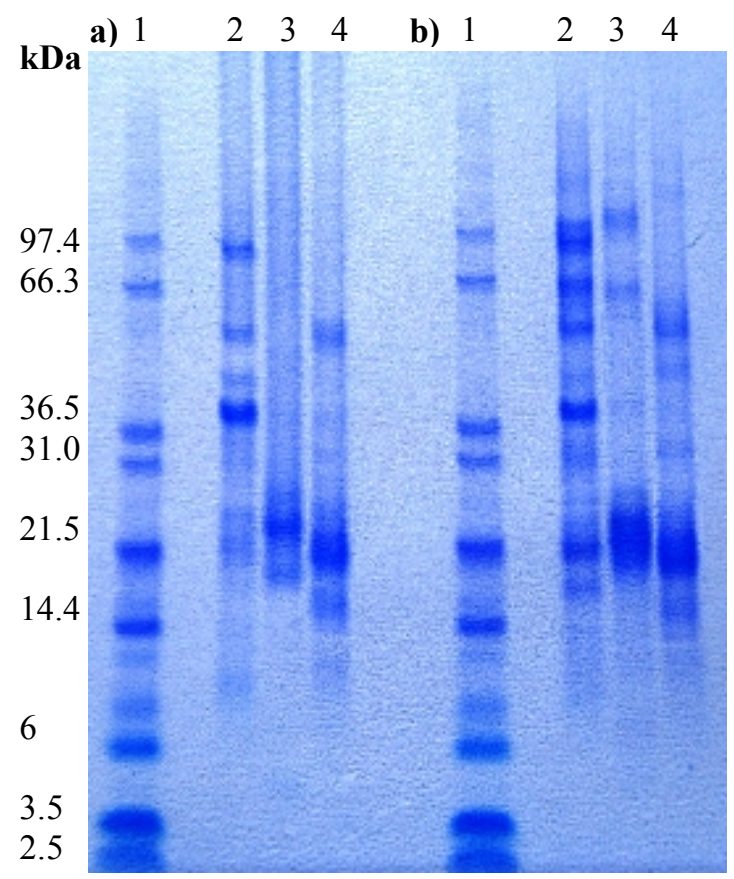

Fig. 1: SDS-PAGE of crude protein crude extracts from soybean, marama bean and cowpea under a) reducing and b) non-reducing conditions on 4-12\% polyacrylamide gradient gel stained with Coomassie Brilliant Blue R-250. Lane 1, molecular marker; lane 2, soybean extract; lane 3, marama bean extract; lane 4 , cowpea extract.

protein of each of the respective seeds (Fotso, Aznaza, Pasquet, \& Raymond, 1994; Mujoo, Trinh, \& Ng, 2003; Amonsou, Taylor, Beukes, \& Minnaar, 2012). The molecular weights of soybean, marama bean and cowpea Kunitz-type protease inhibitors are $21.5 \mathrm{kDa}, 23 \mathrm{kDa}$ and $18 \mathrm{kDa}$, respectively (Elfant, Bryant, \& Starcher, 1985; Benjakul, Visessanguan, \& Thummaratwasik, 2000), while Bowman-Birk type protease inhibitors for dicotyledonous seeds are $8 \mathrm{kDA}$ (Prakash et al., 1996).

Although protein bands with correlating molecular weights were visible on the gels, further analysis was required to confirm the presence of protease inhibitors in the protein extracts. Protease inhibitor activity was present in all the seed extracts and was visible as clear zones against a violet background (Fig. 2). 


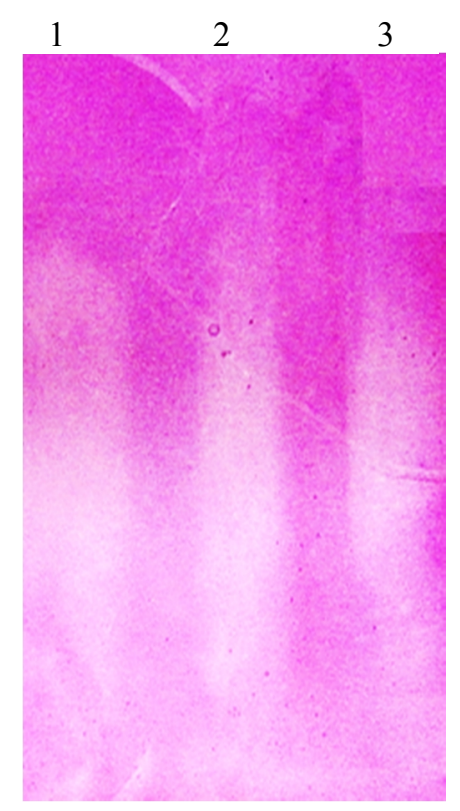

Fig. 2: Native-PAGE gel showing protease inhibitor activity of protein extracts visible as clear zones against a violet background. Lane 1, soybean extract; lane 2, marama bean extract; lane 3, cowpea extract.

Protease inhibitors are usually found in plant storage organs, such as seeds and tubers, and may accumulate to about 1 to $10 \%$ of the total proteins of these storage tissues (De Leo et al., 2002). Trypsin inhibitor activity was present in all three seed extracts (Table 1). The marama bean extracts had the highest specific activity (617.4 TIU/mg protein), followed by soybean extracts with specific activity of $148.1 \mathrm{TIU} / \mathrm{mg}$ protein and then protein extracts from cowpeas (34.4 TIU/mg protein). The trypsin inhibitor activity of the soybean extracts was 52.7 TIU per mg sample and falls within the range of values for different soybean cultivars (43-85 TIU/mg sample) reported by Guillamón et al. (2008). The trypsin inhibitor activity was almost five times higher in the marama bean extracts as compared to the soybean extracts. This value is slightly higher than that reported by Maruatona (2008), but lower than values reported by Bower, Hertel, Oh, and Storey (1988), who found the trypsin inhibitor activity of marama bean to be four and a half and six times more than that found in 
Table 1: Protein content and trypsin inhibitor activity (TIA) of extracts of defatted flour from soybeans, defatted flour from marama beans and flour from cowpeas ${ }^{\mathrm{a}}$

\begin{tabular}{|c|c|c|c|c|c|}
\hline Legume & $\begin{array}{l}\text { TIA } \\
\text { (TIU.mL extract } \\
{ }^{-} \text {) }\end{array}$ & $\begin{array}{l}\text { Protein } \\
\text { (mg.mL extract } \\
\left.{ }^{-}\right)\end{array}$ & $\begin{array}{l}\text { Specific activity } \\
\text { (TIU.mg protein } \\
{ }^{1} \text { ) }\end{array}$ & $\begin{array}{l}\text { TIA } \\
\text { (TIU.mg sample } \\
{ }^{1} \text { ) }\end{array}$ & $\begin{array}{l}\text { Total Phenolics } \\
\text { (mg CE.100 mg } \\
{ }^{1} \text { ) }\end{array}$ \\
\hline Soybeans & $2636.8(15.7)^{\mathrm{B}}$ & $17.8(1.5)^{\mathrm{B}}$ & $148.1^{\mathrm{B}}$ & $52.7^{\mathrm{B}}$ & $0.5(0.1)^{\mathrm{B}}$ \\
\hline Marama beans & $12780.4(30.6)^{\mathrm{C}}$ & $20.7(1.8)^{\mathrm{C}}$ & $617.4^{\mathrm{C}}$ & $255.6^{\mathrm{C}}$ & $1.8(0.1)^{\mathrm{C}}$ \\
\hline Cowpeas & $375.1(11.4 .)^{\mathrm{A}}$ & $10.9(0.8)^{\mathrm{A}}$ & $34.4^{\mathrm{A}}$ & $7.5^{\mathrm{A}}$ & $0.2(0.1)^{\mathrm{A}}$ \\
\hline
\end{tabular}

${ }^{\mathrm{a}}$ TIA of protein extracts in $0.1 \mathrm{M}$ phosphate buffer was expressed as trypsin inhibitor units (TIU) per $\mathrm{mL}$. Total phenolics were expressed as $\mathrm{mg}$ catechin equivalents (CE) per $100 \mathrm{mg}$. Values were expressed as mean values with standard deviation in parenthesis. Values with different superscripts in columns represent significant differences $(\mathrm{p}<0.05)$. Three replicates were used for data analysis.

soybeans, respectively. This variation in trypsin inhibitor activity of marama beans may be due to a difference in the extraction method or cultivars used. The trypsin inhibitor activity of the cowpea protein extracts was the lowest with a trypsin inhibitor concentration of only 7.5 TIU per mg sample and in agreement with RivasVega et al. (2006) who recorded the trypsin inhibitor concentration in cowpeas to be 7.7 TIU per mg of dry sample.

Phenolic compounds may also play a role in enzyme inhibition by forming phenolicprotein complexes with the enzymes (Shahidi \& Naczk, 1992), thus lowering the activity of the enzymes. The total phenolic content of the crude protein extracts showed a trend similar to that of the protease inhibitor concentration, with marama bean extract having the highest total phenolic content (1.8 $\mathrm{mg} \mathrm{CE} / 100 \mathrm{mg}$ sample), followed by that of the soybean extract $(0.5 \mathrm{mg} \mathrm{CE} / 100 \mathrm{mg}$ sample) and then the cowpea extract $(0.2 \mathrm{mg} \mathrm{CE} / 100 \mathrm{mg}$ sample). These concentrations were lower than those reported in literature (Malenčić, Popović, \& Miladinović, 2007; Van Zyl, 2007) and may be due differences in varieties used, agrotechnical and cultural conditions (Naczk \&Shahidi, 2006).

\subsection{Inhibition of protease activity in buffer}

The protein extracts and purified soybean trypsin inhibitor were able to inhibit the bacterial proteases in buffer and the inhibition increased with increased protease 
inhibitor activities (Fig. 3). While the legume protease inhibitors were very effective in inhibiting the activity of serine proteases from Bacillus spp. (i.e. Savinase and Alcalase), reducing the activity of these enzymes by more than $91 \%$ at an activity of $375 \mathrm{TIU} / \mathrm{mL}$, they were less effective in doing so with $P$. fluorescens proteases. Marama bean and soybean extracts showed the highest inhibitory action against $P$. fluorescens proteases with inhibition of 10, 14 and 19\% over the increasing activities of the inhibitor. Pseudomonas species mainly produce only one type of proteinase, typically a neutral zinc metallo-protease (Fairbairn \& Law, 1986; Kohlmann et al., 1991).

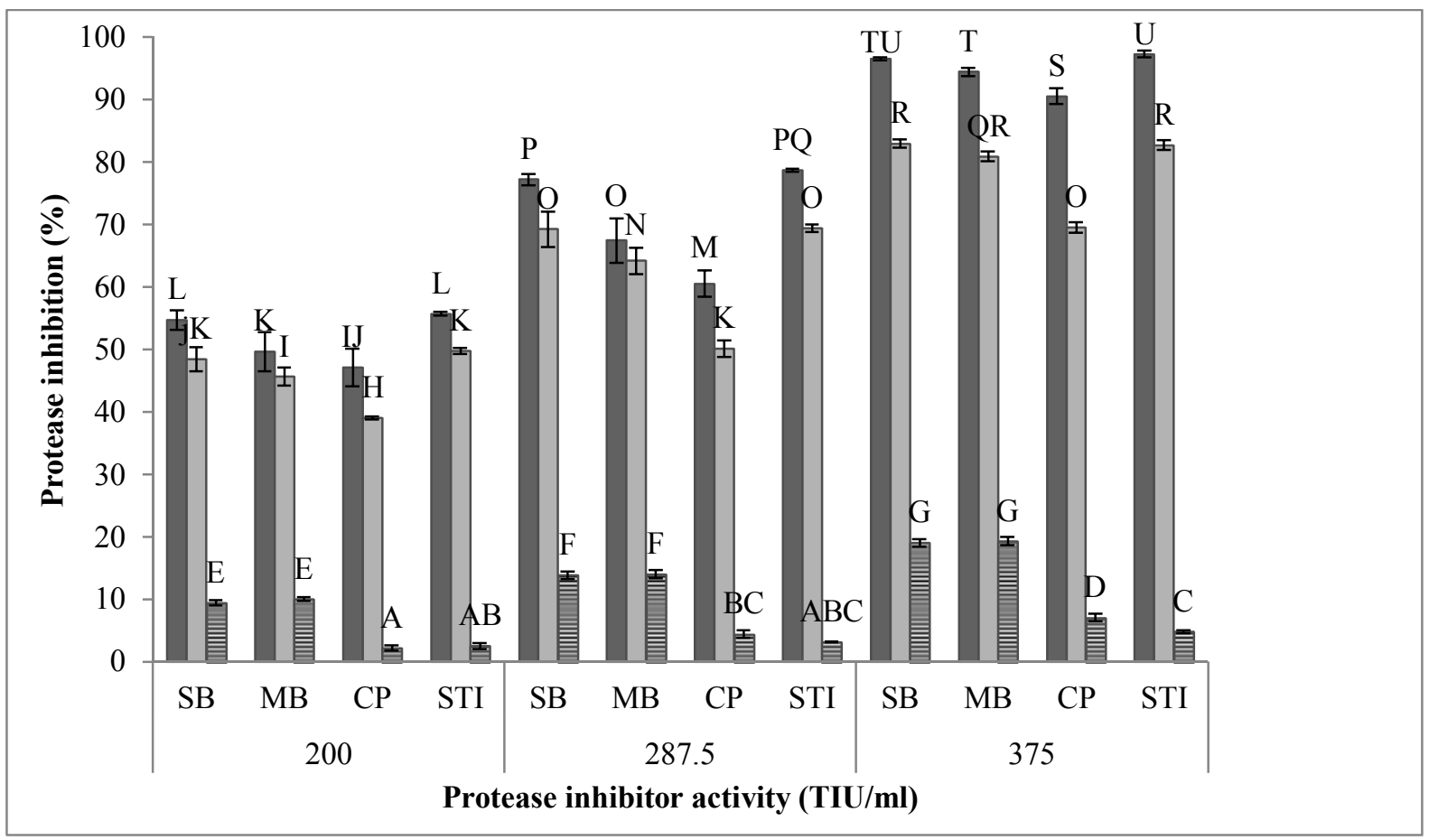

Fig. 3: Inhibition of Savinase $(\square)$, Alcalase $(\square)$ and P. fluorescens (立) proteases in phosphate buffer by treatment with soybean extract (SB), marama bean extract (MB), cowpea extract (CP) and purified soybean trypsin inhibitor (STI). Protease inhibition was measured using azocasein as substrate $(n=3)$. Differences in bar labels $(A-U)$ represent significant differences $(p<0.05)$.

The protease inhibitors commonly found in legumes are serine protease inhibitors (Laskowski \& Kato, 1980; Laing \& McManus, 2002). Serine proteases are generally inhibited by direct blockage of the active site when a substrate-like complex is formed between the enzyme's active site and a canonical protease-binding loop formed by the inhibitor (Bode \& Huber, 2000), while metallo-proteases are inhibited 
by various mechanisms, including one with a rigid protease-binding loop (FernandezCatalan et al., 1998). Even though the latter mechanism resembles that of canonical inhibitors of serine proteases, the specificity of the inhibitors is only towards some and not all of the mechanistic classes of proteases (i.e. serine, cysteine, asparitic and metallo-proteases). The two families of protease inhibitors found in legume seeds, Kunitz type and Bowman Birk protease inhibitors, are mainly specific towards serine proteases, with the Kunitz type protease inhibitors also showing some specificity towards cysteine and aspartic proteases (Odani \& Ikenaka, 1976; Ritonja et al., 1990; Laing \& McManus, 2002). This may explains why the legume protease inhibitors only inhibited the activity of $P$. fluorescens protease to a limited extent.

The purified soybean trypsin inhibitor was very successful in reducing the activity of Savinase and Alcalase, with inhibition of $50-97 \%$, but it was less effective than any of the crude protein extracts in inhibiting the activity of $P$. fluorescens proteases, with inhibition of just over $4 \%$ at the highest inhibitor concentration. Different concentrations of the soybean and marama bean extracts reduced the activity of $P$. fluorescens protease by $9-18 \%$ and $10-19 \%$, respectively. Even cowpea extracts showed higher protease inhibition towards P. fluorescens proteases as compared to the purified trypsin inhibitor. This may be due to the presence of phenolic compounds in the extracts that can form phenolic-protein complexes with the enzymes, since soybean and marama bean extracts had the highest total phenolic contents and also showed the highest level of $P$. fluorescens protease inhibition.

Analysis of the results obtained when plasmin was treated with the legume crude extracts (Fig. 4) indicate that marama bean extracts were the most effective in reducing the activity of this enzyme, inhibiting $50 \%$ of the plasmin activity at a concentration of $200 \mathrm{TIU} / \mathrm{ml}, 70 \%$ at $285.7 \mathrm{TIU} / \mathrm{mL}$ and $94 \%$ at a activity of 375 TIU/mL. Soybean extracts and purified soybean trypsin inhibitors also showed high levels of inhibition with $45-90 \%$ and $46-92 \%$ inhibition, respectively. Although extracts from cowpeas were also able to inhibit some of the plasmin activity, the level of inhibition was lower than those of the other extracts ranging from $35-81 \%$. 


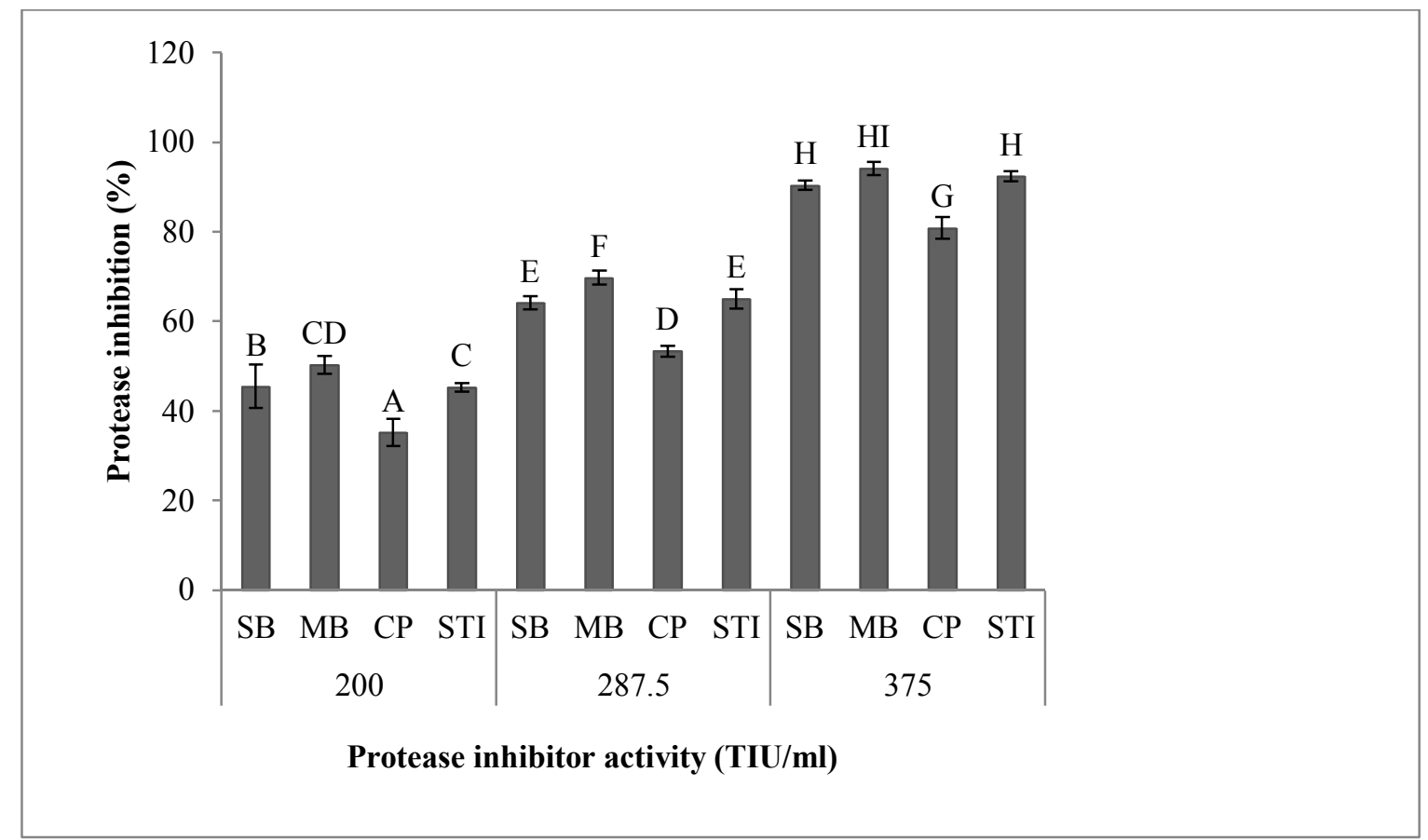

Fig. 4: Inhibition of plasmin by treatment with soybean extract (SB), marama bean extract (MB), cowpea extract (CP) and purified soybean trypsin inhibitor (STI). Plasmin activity was measured using a colorimetric assay with Val-Leu-Lys-p-nitroanilide as substrate $(n=3)$. Differences in bar labels (A-I) represent significant differences $(\mathrm{p}<0.05)$.

\subsection{Inhibition of protease activity in low fat UHT milk}

Since the protein extracts and the purified soybean trypsin inhibitor showed good protease inhibition towards the enzymes in buffer, the ability of these extracts to reduce the activity of these enzymes in low fat UHT milk was tested.

Table 2: The effect of legume crude protein extracts on protease activity in low fat UHT milk

\begin{tabular}{lllll}
\hline & \multicolumn{3}{c}{ \% Inhibition } \\
\cline { 2 - 5 } Protease & $\begin{array}{l}\text { Soybean } \\
\text { extract }\end{array}$ & $\begin{array}{l}\text { Marama bean } \\
\text { extract }\end{array}$ & $\begin{array}{l}\text { Cowpea } \\
\text { extract }\end{array}$ & $\begin{array}{l}\text { Purified soybean } \\
\text { trypsin inhibitor }\end{array}$ \\
\hline Savinase & $44.7(0.4)^{\mathrm{C}}$ & $36.1(0.8)^{\mathrm{B}}$ & $28.3(3.7)^{\mathrm{A}}$ & $49.8(0.5)^{\mathrm{D}}$ \\
Alcalase & $38.8(1.3)^{\mathrm{C}}$ & $34.9(0.7)^{\mathrm{B}}$ & $23.7(1.5)^{\mathrm{A}}$ & $42.5(0.7)^{\mathrm{D}}$ \\
$\boldsymbol{P}$. fluorescens $^{\text {flus }}$ & $4.1(0.2)^{\mathrm{C}}$ & $3.6(0.6)^{\mathrm{C}}$ & $2.1(0.5)^{\mathrm{B}}$ & $1.2(0.2)^{\mathrm{A}}$ \\
Plasmin & $38.5(1.1)^{\mathrm{B}}$ & $39.8(1.0)^{\mathrm{B}}$ & $26.5(0.9)^{\mathrm{A}}$ & $41.2(0.7)^{\mathrm{C}}$
\end{tabular}

$\overline{{ }^{a}}$ Proteases and protease inhibitors were added to low fat UHT milk and incubated at $25^{\circ} \mathrm{C}$ for $1 \mathrm{~h}$.

Activity of bacterial proteases and plasmin were determined with RP-HPLC and a colorimetric assay, respectively. Values expressed as mean values with standard deviation in parenthesis. Values with different superscripts in rows represent significant differences $(\mathrm{p}<0.05)$. Three replicates were used for data analysis. 
All the protease inhibitor extracts and the purified soybean trypsin inhibitor were able to inhibit the activity of Savinase, Alcalase and plasmin in low fat UHT milk, but to different extents (Table 2). The purified soybean trypsin inhibitor showed the highest protease inhibition towards Savinase, Alcalase and plasmin and reduced the activity of these enzymes by $50 \%, 43 \%$ and $41 \%$, respectively. Comparing all the legume seed extracts, soybean was the most effective in reducing the activity of Savinase and Alcalase, followed by the marama bean extract and then the cowpea extract. The level of plasmin inhibition in the UHT milk was similar for marama bean and soybean extracts $(39.8 \%$ and $38.5 \%$ respectively). Even though the marama bean extracts were the most effective in inhibiting the activity of plasmin in buffer, the purified soybean trypsin inhibitor was more effective in inhibiting this enzyme in the low fat UHT milk. This may be due to the presence of phenolic compounds in the extracts that had an effect on the enzymes in buffer, but less so in the UHT milk possibly due to the presence of more proteins that they could bind to.

As shown earlier, the legume protease inhibitors had a limited effect on the activity of $P$. fluorescens proteases. None of the protease inhibitors were able to reduce the activity of the $P$. fluorescens protease by more than $4 \%$. The highest level of inhibition was, however, again achieved with the protein extracts that contain phenolic compounds that may play a role in the inhibition.

Analysis of the results obtained when the extracts were used to inhibit proteases in UHT milk indicate that they were less effective in reducing the activity of these enzymes in milk as compared to buffer. This may be due to the milk proteins occupying the active sites of the proteases before the protease inhibitors, reducing the efficacy of the protease inhibitors in the milk as compared to the buffer system.

\section{Conclusions}

From the results obtained, it is evident that the legume protease inhibitors show great potential in preventing or reducing proteolytic activity of Bacillus proteases and plasmin and may be exploited in various applications where these proteases cause sensory or consistency defects in products. Defects caused by $P$. fluorescens enzymes will, however, not be reduced by these protease inhibitors. Further studies need to be 
conducted to determine the effect of protease inhibitors on the sensory and biochemical properties of the milk and also how it can be used to comply with laws and regulations of governing milk authorities.

\section{References}

Amonsou, E. O., Taylor, J. R. N., Beukes, M., \& Minnaar, A. (2012). Composition of marama bean protein. Food Chemistry, 130, 638-643.

Aroonkamonsri, J. H., Aroonkamonsri, W., \& Kakuda, Y. (1996). The role of plasmin and bacterial proteinases on age gelation of UHT milk. Scanning, 18, 203204.

Aroonkamonsri, J.H., Aroonkamonsri, W., \& Kakuda, Y. (1996). The role of plasmin and bacterial proteinases on age gelation of UHT milk. Scanning, 18, 203-204.

Baldi, A., Savoini, G., Cheli, F., Fantuz, F., Senatore, E., Bertocchi, L., \& Politis, I. (1996). Changes in plasmin-plasminogen-plasminogen activator in milk from Italian Friesian herds. International Dairy Journal, 6, 1045-1053.

Benjakul, S., Visessanguan, W., \& Thummaratwasik, P. (2000). Isolation and characterisation of trypsin inhibitors from some Thai legume seeds. Journal of Food Biochemistry, 24, 107-127.

Bode, W., \& Huber, R. (2000). Structural basis of the endoproteinase- protein inhibitor interaction. Biochimica et Biophysica Acta, 1477, 241-252.

Bower, N., Hertel, K., Oh, J., \& Storey, R. (1988). Nutritional evaluation of marama bean (Tylosema esculentum, Fabaceae): Analysis of the seed. Economic Botany, 42, 533-540.

Bradford, M. M. (1976). A rapid and sensitive method for the quantitation of microgram quantities of protein utilizing the principle of protein-dye binding. Analytical Biochemistry, 72, 248-254. 
Chen, L., Daniel, R. M., \& Coolbear, T. (2003). Detection and impact of protease and lipase activities in milk and milk powders. International Dairy Journal, 13, 255275.

Datta, N., \& Deeth, H. C. (2001). Age gelation of UHT milk - A Review. Food and Bioproducts Processing, 79, 197-210.

Datta, N., \& Deeth, H. C. (2003). Diagnosing the cause of proteolysis in UHT milk. LWT-Food Science and Technology, 36, 173-182.

De Leo, F., Volpicella, M., Licciulli, F., Liuni, S., Gallerani, R., \& Ceci, L. R. (2002). Plant-PIs: a database for plant protease inhibitors and their genes. Nucleic Acids Research, $30,347-348$.

Ee, K.Y., Zhao, J., Rehman, A., \& Agboola, S. (2008). Characterization of trypsin and $\alpha$-chymotrypsin inhibitors in Australian wattle seed (Acacia victoriae Bentham). Food Chemistry, 107, 337-343.

Elfant, M., Bryant, L., \& Starcher, B. (1985). Isolation and characterization of proteinase inhibitor from marama beans. Experimental Biology and Medicine, 180, 329333.

Fairbairn, D. J., \& Law, B. A. (1986). Proteinases of psychrotrophic bacteria: Their production, properties, effects and control. Journal of Dairy Research, 53, 139-177.

Fernandez-Catalan, C., Bode, W., Huber, R., Turk, D., Calvete, J. J., Lichte, A., Tschesche, H., \& Maskos, K. (1998). Crystal structure of the complex formed by the membrane type 1-matrix metalloproteinase with the tissue inhibitor of metalloproteinases-2, the soluble progelatinase A receptor. European Molecular Biology Organization Journal, 17, 5238-5248.

Fotso, M., Azanza, J.L., Pasquet, R., \& Raymond, J. (1994). Molecular heterogeneity of Cowpea (Vigna unguiculata Fabaceae) seed storage proteins. Plant Systematics and Evolution, 191, 39-56.

Gebre-Egziabher, A., Humbert, E. S., \& Blankenagel, G. (1980). Hydrolysis of milk proteins by microbial enzymes. Journal of Food Protection, 43, 709-712. 
Grufferty, M. B. \& Fox, P. F. (1988). Milk alkaline proteinase. Journal of Dairy Research, 55, 609-630.

Guillamón, E., Pedrosa, M. M., Burbano, C., Cuadrado, C., de Cortes Sánchez, M., \& Muzquiz, M. (2008). The trypsin inhibitors present in the seed of different grain legume species and cultivar. Food Chemistry, 107, 68-74.

Hagerman, A., Harvey-Mueller, I., \& Makkar, H. P. S. (2000) Quantification of Tannins in Tree Foliage - a Laboratory Manual. Vienna: FAO/IAEA.

Kohlmann, K. L., Nielsen, S. S., \& Ladisch, M. R. (1991). Effects of a low concentration of added plasmin on ultra-high temperature processed milk. Journal of Dairy Science, 74, 1151-1156.

Laing, W., \& McManus, M. T. (2002). Proteinase inhibitors. In M.T. McManus, W.A. Laing, \& A.C. Allan (Eds.), Protein-Protein Interactions in Plant Biology (pp. 77119). Florida: CRC Press.

Laskowski, M., \& Kato, I. (1980). Protein inhibitors of proteinases. Annual Reviews in Biochemistry, 49, 593-626.

Law, B. A., \& Mabbitt, L. A. (1983). New methods for controlling the spoilage of milk and milk products. In T.A. Skinner, \& F.A. Robberts (Eds.), Food microbiology: Advances and prospects (pp. 131-150). New York: Academic Press Inc.

Le, T. X., Datta, N., \& Deeth, H. C. (2006). A sensitive HPLC method for measuring bacterial proteolysis and proteinase activity in UHT milk. Food Research International, 39, 823-830.

Lorier, M. A., \& Aitken, B. L. (1990). Method for treating fish with alpha-2macroglobulin. United States Patent 5013568.

Lu, D. D., \& Nielsen, S. S. (1993). Heat inactivation of native plasminogen activators in bovine milk. Journal of Food Science, 58, 1010-1012.

Malenčić, D., Popović, M., \& Miladinović, J. (2007). Phenolic content and antioxidant properties of soybean (Glycine max (L.) Merr. ) seeds. Molecules, 12, 576-581. 
Maggo, S., Malhotra, S. P., Dhawan, K., \& Singh, R. (1999). Purification and characterization of protease inhibitor from rice bean (Vigna umbellata T.) seeds. Journal of Plant Biochemistry and Biotechnology, 8, 61-64.

Maruatona, G. N. (2008). Physico-chemical, nutritional and functional properties of defatted marama bean flour. MSc Food Science dissertation, University of Pretoria, Pretoria, S.A.

Matta, H., \& Punj, V. (1999). Isolation and identification of lipolytic psychrotrophic spore forming bacteria from raw milk. International Journal of Dairy Technology, 52, $59-62$.

Matselis, E. \& Roussis, I. G. (1998). Proteinase and lipase production by Pseudomonas fluorescens. Proteolysis and lipolysis in thermized ewe's milk. Food Control, 9, 251-259.

McMahon, D. J. (1995). Age-gelation of UHT milk: Changes that occur during storage, their effect on shelf life and the mechanism by which age-gelation occurs. In IDF Symposium, Vienna, Heat treatments and alternative methods (pp. 315-326). Brussels: International Dairy Federation.

Mujoo, R., Trinh, T. D., \& Ng, K. W. P. (2003). Characterisation of storage proteins in different soybean varieties and their relationship to tofu yield and texture. Food Chemistry, 82, 265-273.

Naczk, M., \& Shahidi, F. (2006). Phenolics in cereals, fruits and vegetables: occurrence, extraction and analysis. Journal of Pharmaceutical and Biomedical Analysis, 41, 1523-1542.

Odani, S., \& Ikenaka, T. (1976). The amino acid sequences of two soybean double headed proteinase inhibitors and evolutionary consideration on the legume proteinase inhibitors. Journal of Biochemistry, 80, 641-643.

Peréz-Mateos, M., Montero, P., \& Gómez-Guillén, M. C. (2002). Addition of microbial transglutaminase and protease inhibitors to improve gel properties of frozen squid muscle. European Food Research and Technology, 214, 377-381. 
Phillips, J. D., \& Griffiths, M. W. (1990). Pasteurized dairy products: the constraints imposed by environmental contamination. In O.J. Simmons, \& M.S. Nriagu (Eds.), Food contamination from environmental sources (pp. 387-486). New York: Wiley.

Prakash, B., Selvaraj, S., Murthy, M. R., Sreerama, Y. N., Rao, D. R., \& Gowda, L. R. (1996). Analysis of the amino acid sequences of plant Bowman-Birk inhibitors. Journal of Molecular Evolution, 42, 560-569.

Richardson, B., \& Pearce, K. (1981). The determination of plasmin in dairy products. New Zeeland Journal of Dairy Science and Technology, 16, 209-220.

Ritonja, A., Krizaj, I., Mesko, P., Kopitar, M., Lucovnik, P., Strukelj, B., Pungercar, J., Buttle, D. J., Barrett, A. J., \& Turk, V. (1990). The amino acid sequence of a novel inhibitor of cathepsin D from potato. FEBS. Letters, 267, 13-15.

Rivas-Vega, M. E., Goytortúa-Bores, E., Ezquerra-Brauer, J. M., Salazar-García, M. G., Gruz-Suárez, L. E., Nolasco, H., \& Civera-Cerecedo, R. (2006). Nutritional value of cowpea (Vigna unguiculata L. Walp) meals as ingredients in diets of Pacific white shrimp (Litopenaeus vannamei Boone). Food Chemistry, 97, 41-49.

Secades, P., \& Guijarro, J. A. (1999). Purification and characterisation of extracellular protease from fish pathogen Yersinia ruckeri and effect of culture conditions on production. Applied and Environmental Microbiology, 65, 3969-3975.

Shahidi, F., \& Naczk, M. (1992). An overview of the phenolics of canola and rapeseed: Chemical, sensory and nutritional significance. Journal of the American Oil Chemists Society, 69, 917-924.

Sørhaug T., \& Stepaniak, L. (1997). Psychrotrophs and their enzymes in milk and dairy products: quality aspects. Trends in Food Science \& Technology, 8, 35-41.

Taylor, J., Bean, S. R., Ioerger B. P., \& Taylor, J. R. N. (2007). Preferential binding of sorghum tannins with $\gamma$-kafirin and the influence of tannin binding on kafirin digestibility and biodegradation. Journal of Cereal Science, 46, 22-31.

Upadhyay, V. K., McSweeney, P. L. H., Magboul, A. A. A., \& Fox, P. F. 2004. Proteolysis in cheese during ripening. In P.L.H. Mc Sweeney, T.M. Cogan , T.P. 
Guinee, \& P.F. Fox (Eds), Cheese - Chemistry, Physics and Microbiology (pp. 391396). London: Academic Press.

Van Zyl, L. (2007). Phenolic content and antioxidant activity of marama bean (Tylosema esculentum). BSc (Agric.) Food Science and Technology Project Report. University of Pretoria, Pretoria, South Africa.

Visser, S. (1981). Proteolytic enzymes and their action on milk proteins. A review. Netherlands Milk and Dairy Journal, 35, 65-88. 